\title{
UNDERGRADUATE BUSINESS STUDENTS' ATTITUDES TOWARDS CSR AND COMPETITIVENESS OF SERBIAN ECONOMY
}

\author{
UDC: $005.35: 339.137 .2$ \\ Original Scientific Paper

\section{Dragan ĆOĆKALO ${ }^{1}$, Dejan ĐORĐEVIĆ ${ }^{1}$, Bešić CARIŠA ${ }^{2}$, Srđan BOGETIĆ $^{3}$}
${ }^{1}$ University of Novi Sad, Technical faculty “Mihajlo Pupin” Zrenjanin, 23000 Zrenjanin, Đure Đakovića bb, Republic of Serbia
E-mail: cole@ttzr.uns.ac.rs; dragan.cockalo@ttzr.rs
${ }^{2}$ University of Kragujevac, Faculty of technical science, 32000 Čačak, 65 Svetog Save, Republic of Serbia
${ }^{3}$ Belgrade Business School, 11000 Belgrade, Kraljice Marije 73, Republic of Serbia

Paper received: 23.04.2015.; Paper accepted: 04.05.2015.

\begin{abstract}
This paper presents the findings of the research dealing with the importance of corporate social responsibility (CSR) and its connections with competitiveness. The authors deal with competitiveness of enterprises, as well as activities that promote socially responsible business in Serbia. Special attention is given to the review and analysis of research results of Serbian undergraduate business students' attitudes on CSR and competitiveness. In a five-year- period the research included over 3,300 examinees. The population was built on students from universities and business schools located in total 22 cities and municipalities in Serbia. The research was conducted using questionnaire. Among other, the research has shown that a number of examinees were not informed of the CSR. Students experience the Serbian economy as uncompetitive and have identified several factors that are lacking in the development of competitiveness.
\end{abstract}

Key words: corporate social responsibility, competitiveness, education, students, Serbia.

\section{INTRODUCTION}

CSR as a concept enables a company to be competitive at the market. The imperative for any business enterprise is to achieve business excellence, and its three pillars are: meeting the demands of users, improving business productivity and CSR. The first two steps result in a profit, but without the social responsibility of business there is no excellence of the companies. The essence of the struggle for competitiveness lies in the acceptance of change. Companies from countries in transition are facing huge problems, where the dominant issues are related to knowledge advancement and the organization. Serbian companies are insufficiently competitive and global economic crisis has only highlighted this fact.

Corporate Social Responsibility (CSR) was introduced in the 1970's, but different forms of this concept date back to the end of 19th century. At the beginning the focus of the company in the field of CSR involved only certain philanthropic activities, i.e., donating charity funds. Recently, CSR initiatives have used different nomenclatures, classifications and definitions which can be grouped in several dimensions (Ćoćkalo et al. 2014): (1) Vision, including the organizational conceptual development, governance, ethical codes, values and reputation; (2) Company's relations with the community - collaborations and partnerships with stakeholders, philanthropy and action; (3) Workplace, labor practices and human rights; (4) Corporate transparency, reporting and communication and (5) Marketplace - research and development, pricing, fair competition, marketing and investment.

It is important for the organizations to deal with social responsibility, regardless of social or economic circumstances. Instruments such as the Declaration on Environment and Development in Rio, Declaration on Sustainable Development in Johannesburg Summit, the Millennium Declaration and the ILO fundamental principles and rights 
related to labor, emphasize this need, (Global Compact, 2014; ILO Declaration, 2014; OECD Guidelines, 2014; SMART: Responsible Business, 2014). The European Commission, in 2010, defined CSR as "a concept, which integrates into the enterprise the concern for society and the environment in their business activities and their interaction with their stakeholders on a voluntary basis", (Milosavljević, 2012).

Almost the main management question in this matter is: whether implementing CSR affects firm competitiveness (Chand and Fraser, 2006; Haigh and Jones, 2006; Porter and Kramer, 2006). Many authors (Porter and Van Der Linde, 1995; Bansal and Roth, 2000; Hess et al., 2002; Haigh and Jones, 2006) have suggested that competitiveness is one of the primary drivers for adopting a CSR concept, though the nature of relationship between CSR and competitiveness continues to be unclear (Harrison and Freeman, 1999; Porter and Kramer, 2006). In this way, according to Vilanova, Lozano and Arenas (2008), the CSR - competitiveness connection is made of three management processes: “(a) strategy, (b) stakeholder management and (3) accountability". Further, according to these authors, adoption of a CSR strategy effects on "identity and branding, which has a direct impact on competitiveness as it forces sustainable development in corporate vision through corporate strategy, improves the understanding of the complexity of the competitive environment and strengthens relationships with key stakeholders through stakeholder management, and improves the transparency of the organization through accountability management processes."

Success of CSR in the future depends on the attitudes of the next generations. They will create the relations between business and the society, no matter whether he is a common citizen, a consumer or a manager. It seems that the young generations are considered to be more open to social and environmental issues, promising thus a more optimistic future for CSR. Position of institutions of higher education in the society is unique - they are important places of knowledge production, perpetuation and dissemination. In addition to these conventional associations of universities and knowledge, higher education institutions have unique potential to encourage synthesis and integration of different types of knowledge and to enhance the application of knowledge to social change. The number of study programs in business schools that have integrated optional courses in
CSR or specialized programs is increasing, (Matten and Moon, 2004).

The CSR courses that the present managers and future managers have attended did not bring them to lead a responsible social behavior in their firms - a generalization of good practices in this field research is missing. The global crisis, according to Kletz (2009), brings the paradox: "managers knowing the importance of a socially responsible behavior, knowing how to behave in a socially responsible way, and gladly highlighting its importance - have in fact turned their back to it." McWilliams and Siegel (2001) indicate to determinable 'ideal' level of CSR, which managers can predict using cost-benefit analysis. Responsibility is no longer exclusive in the domain of moral value, and it is legitimate to give it up when the price is too high, in terms of company's competitiveness - when responsibility becomes too expensive, (Kletz, 2009).

The significant number of studies deals with the question whether business schools are no more than brainwashing institutions educating their graduates only in relatively narrow shareholder value ideology. Others have concluded that there is an "intellectual bias against business ethics" in business schools and that teaching and research in business ethics and similarly oriented areas, (Hosmer, 1999). While the majority of studies have focused on North American schools and a good number on related subjects such as marketing and ethics (Shannon and Berl, 1997), sustainability- profitability (Wheeler et al., 2002), only limited attention has been directed at the topic from a European perspective (Matten and Moon, 2004). The Western Balkan countries have not been an area of significant research in the field of CSR, especially topics related to education - CSR - competitiveness. This paper reports on the findings of a survey dealing with attitudes of students related to CSR and competitiveness of the Serbian economy and promotion of these terms.

\section{CSR AND COMPETITIVENESS OF SERBIAN ECONIMY}

In order to better promote the concept of CSR, the Fund for an Open Society, SMart Kolektiv and Chamber of Commerce and Industry of Serbia launched, nearly ten years ago, a project called "SMART: Responsible Business Initiative - RBI", with purpose to promote and institutionalize the concept of social responsibility in Serbia. From that time to the present, a lot has been done in this 
area, and on its further promotion on the Serbian market. Since then, the main promoters of CSR on the Serbian market are the Balkan Community Initiatives Fund (BCIF), SMart Collective and Chamber of Commerce and Industry of Serbia.

The Balkan Community Initiatives Fund (BCIF), in cooperation with USAID and several other national and international organizations launched in 2007 Virtus award with the aim of further popularization of CSR in the Serbian market. Virtus Award is conferred to the present eight times in a row, where winners were foreign companies, public and state-owned enterprises, small and medium enterprises, media companies, corporate funds and foundations. If analyze the structure of the business award winners for period of 2007-2014., the conclusion is that most awards went to the financial sector and banks (15 in total). Serbian financial institutions which conduct concept of CSR in its operations are: the National Bank of Serbia, Erste Bank, Societe Generale, Banca Intesa, EFG Eurobank. After banking, the most first prizes were given to media, especially emedia: B92 and RTS. The organizations, winners of Virtus award for 2014 (Virtus Award Winners) are: Hemofarm a.d., Vršac (nominated for company contribution on the national level), Concern Bambi d.o.o., Požarevac (nominated for their contribution to local community in which they perform business), Spa Komerc Bekament d.o.o., Aranđelovac (SME nominated for their support to sports associations, cultural institutions, charity organizations and municipalities endangered by floods), Phillip Morris Operations a.d. (nominated for long-lasting partnership of business and non-profit sector), Kotlenik d.o.o, Coca Cola HBC Serbia and Delta Holding.

Chamber of Commerce and Industry of Serbia in 2007 for the first time began to award prizes for CSR, and since 2008, the prize has been awarded every two years. Unlike other awards in this field, its role is to try to treat equally various business segments. The questionnaire, which is the basis for the methodology covers five areas of CSR including: employees, environment, market, property and communities. Companies that want to compete for the prize as Chamber of Commerce and Industry of Serbia CSR can be nominated in two categories: large enterprises and SMEs. The winners of the first prize were: Tigar from Pirot (large enterprises category) and a company Biovoda from Bujanovac (SME category) were declared as the most responsible companies in Serbia in 2007. In the category of large companies, the reward in the next three years was given to Metalac Gornji Milanovac, Eurobank EFG and Hemofarm a.d. Vršac, while in the SME category the award went to the Footwear Pavle, Sunce Marinkovic and S.C.S. Plus Knjaževac.

However, despite national strategy and translated standards ISO 26000:2011, the concept of CSR has not yet been adequately developed as one would wish. Serbian companies still do not understand the wide range of activities offered by the concept of CSR, and are concerned mostly about casual philanthropy and volunteering activities, (Ivanović-Đukić, 2011). Serbian managers, unfortunately, as part of its business philosophy, insufficiently implemented principles of CSR, which significantly affects the competitiveness of Serbian firms, in the domestic and international markets, (Bogetić et al., 2013). The reason for this attitude towards CSR lies in the fact that the market has insufficiently developed consciousness and strength to punish any company that does not want to be socially responsible, (Milosavljević, 2012). This penalty represents a loss for the company as end user, and thus for the market.

The media - which include television, newspaper and now Internet - are the most distinctive information channels that reach and influence the general public. As such, they play a central role in ensuring that CSR is put in the public spotlight. That is why the CSR promoters must work to reach out the major media journalists who are dealing with this area, talk with them, as well as with business leaders who are the leaders in this field and make the social responsibility of the company become a question that will make economists and politicians and movie stars to think about. Media play two distinct roles in this debate. The traditional media are seen only in the role of someone who is spreading the information. However, the increasing prominence of multinational media group draws attention to what is going on behind the scenes. Local organizations have started lately, as a way of promoting their activities, to use social networks, primarily Facebook and Twitter. The reason for such commitment of companies towards social networks can be found in the fact that there has been an increase in the use of social networks, especially among the younger population, and that this kind of promotion for their products and services cost significantly less. Companies have also started using social networks for representing their own social activities, and thus attracting the target market - young population. 
According to the list of World Economic Forum for 2014-15, Serbia took 94th place out of 144 analyzed countries. Since Serbia took 101st place in 2013-14 there is some progress in competitiveness. It is interesting that Serbia found itself between Lao PDR (93rd place) and Cambodia (95th place). Table 1 shows the ranking of ex-Yugoslav countries in the last five years, according to WEF. Considering the countries from near surroundings, Hungary takes 60th place, Bulgaria 54th, Romania 59th, Albania 97th place. All countries from the West Balkans, except Serbia and Macedonia, fell in comparison to their previous position, according to their competitiveness. Monte Negro kept its previous position, Macedonia considerably improved its competitive position for 17 places and Bosnia and Herzegovina was not included in the Report for 2014-15. Serbian economy is still the most uncompetitive in the region of West Balkans as well as in South East Europe. Table 2 shows the ranking of West Balkan countries according to indices of competitiveness. As we can notice, Serbia has a slightly better position considering business efficiency than innovativeness.

Table 3 shows the ranking of Western Balkan countries in analysis of sustainable development, viewed from the angle of social sustainability and environmental protection sustainability. The main pillars of social index of sustainable development are: income, youth unemployment, access to sanitary facilities, access to drinking water, access to medical service, social protection, share of grey economy in general economy, social mobility, general rate of unemployment. The main pillars of the index in the sphere of environmental protection are: the power of legal regulations, soil protection, the number of ratified international protocols and agreements, availability of water for agriculture, exposure to carbon-dioxide emission, relation to fishing, concentration of particles in the air, quality of the environment.

Table 1: Ranking of West Balkan countries according to competitiveness in the period 2008-2014

\begin{tabular}{|l|l|l|l|l|l|}
\hline Country & $\begin{array}{l}\text { Place } \\
\text { in 2010. }\end{array}$ & $\begin{array}{l}\text { Place } \\
\text { in 2011. }\end{array}$ & $\begin{array}{l}\text { Place } \\
\text { in 2012 }\end{array}$ & $\begin{array}{l}\text { Place } \\
\text { in 2013 }\end{array}$ & $\begin{array}{l}\text { Place } \\
\text { in 2014 }\end{array}$ \\
\hline Slovenia & 45 & 57 & 56 & 62 & 70 \\
\hline Montenegro & 48 & 60 & 72 & 67 & 67 \\
\hline Croatia & 77 & 76 & 81 & 75 & 77 \\
\hline Macedonia & 79 & 79 & 80 & 80 & 63 \\
\hline Serbia & 96 & 95 & 95 & 101 & 94 \\
\hline B and H & 102 & 100 & 88 & 87 & - \\
\hline
\end{tabular}

Source: The Global Competitiveness Report 2008-2014

Table 2: Ranking of West Balkan countries according to competitiveness indices in 2014 (2013)

\begin{tabular}{|l|c|c|c|c|}
\hline Country & $\begin{array}{c}\text { Position in } \\
\text { 2014 (2013) total }\end{array}$ & $\begin{array}{c}\text { Position } \\
\text { according to } \\
\text { basic requirements }\end{array}$ & $\begin{array}{c}\text { Ranking } \\
\text { according to } \\
\text { business efficiency }\end{array}$ & $\begin{array}{c}\text { Ranking } \\
\text { According to } \\
\text { innovativeness }\end{array}$ \\
\hline Slovenia & $70(62)$ & $49(37)$ & $64(62)$ & $50(49)$ \\
\hline Montenegro & $67(67)$ & $61(68)$ & $73(72)$ & $77(70)$ \\
\hline Croatia & $77(75)$ & $63(61)$ & $68(68)$ & $87(80)$ \\
\hline Macedonia & $63(74)$ & $64(70)$ & $69(76)$ & $76(94)$ \\
\hline Serbia & $94(101)$ & $101(106)$ & $80(92)$ & $121(125)$ \\
\hline BandH & $-(87)$ & $-(87)$ & $-(89)$ & $-(89)$ \\
\hline
\end{tabular}

Source: The Global Competitiveness Report 2008-2014

Table 3: Western Balkan countries according to analysis of sustainable development factors in 2014

\begin{tabular}{|l|l|l|l|}
\hline Country & $\begin{array}{l}\text { Ranking according to } \\
\text { social sustainability }\end{array}$ & $\begin{array}{l}\text { Ranking according to } \\
\text { Environmental sustainability }\end{array}$ & $\begin{array}{l}\text { Change in comparison to } \\
\text { the previous period }\end{array}$ \\
\hline Slovenia & 4.52 & 4.78 & GCI score changes by $>+5 \%$ to $+15 \%$ \\
\hline Montenegro & 4.08 & 4.38 & GCI score remains stable between $+5 \%$ and $-5 \%$ \\
\hline Croatia & 4.06 & 4.21 & GCI score remains stable between $+5 \%$ and $-5 \%$ \\
\hline Macedonia & 4.13 & 3.66 & GCI score changes by $<-5 \%$ to $-15 \%$ \\
\hline Serbia & 3.68 & 3.86 & GCI score remains stable between $+5 \%$ and $-5 \%$ \\
\hline BandH & $3,66(2013 \mathrm{GCI})$ & $3,44(2013 \mathrm{GCI})$ & GCI score changes by $<-5 \%$ to $-15 \%$ \\
\hline
\end{tabular}

Source: The Global Competitiveness Report 2008-2014 


\section{METHODOLOGY}

A part of the research which dealt with the analysis of attitudes of students related to their involvement in entrepreneurial process as well as with their comprehension about success of business practice in Serbian companies was related to CSR towards competitiveness of national economy. The survey was carried out by questionnaire. The population was built of students from four universities and business schools. It included totally 3.354 students directed towards business and management. The average age of examinees was about 22 years. About $40 \%$ men and $60 \%$ women participated in the sample. The research from 2013 was the most extensive and it involved 806 students. The research from 2014, although smaller in size (559 students), realized the biggest territory dispersion by its sample and the data from total 22 Serbian towns or municipalities were collected.

Since the CSR is not particularly part of the curricula in Serbia, here we were interested to find out, first of all, whether the students theoretically and practically (through positive examples of business practices) were familiar with the concept of CSR and how they came to these findings. Next, we wanted to see how respondents perceived competitiveness - whether they perceive "the link" between CSR and competitiveness of enterprises. Based on the model which Vilanova et al. (2008) give we have selected certain elements that could affect development of competitiveness of enterprises in Serbia; CSR was one of them. This was supposed to be another "check point" of the original idea.

Specific hypothesis referring to this study were set up as it follows here:

H1: There is a significant difference among the number of examinees who have got acquainted with the term CSR comparing to the year in which the research was carried out.

$\mathrm{H} 2$ : There is a significant connection among the source of information about CSR and the year in which the research was carried out.

H3: There is a connection between the year in which the research was carried out and the number of young people who can number socially responsible companies on domestic market.
H4: There is a connection between the year in which the research was carried out and the number of young people who can find the connection between competitive ability and social responsibility.

Percentage review and frequencies were used for description and category data presentation. For testing the differences among the categories we used hi - square tests as well as the difference tests among proportions with Bonferroni correction used for multiple comparisons. For all examined differences among interval variables we presented arithmetic mean of each group in order to observe the value of the difference. As a significance level we took into consideration $\mathrm{p}<0.05$ both for category and interval variables and it was also stressed if the hypothesis was significant at a stricter significance level $(\mathrm{p}<0.01$ or $\mathrm{p}<0.001)$.

\section{RESULTS ANALYSIS}

Chi-square data test obtained from the asked question "Have you ever heard about CSR?" shows that there are differences in the number of young people who have been acquainted with the notion of CSR depending on the year in which the research was carried out $(\chi 2=135.403, \mathrm{df}=4, \mathrm{p}<$ $0.001)$. The results presented in the figure 1 show that every year the percentage of examinees who were acquainted with CSR was growing, in other words, from only $25 \%$ in 2010 the percentage grew to more than $50 \%$ of the examinees during the previous year. The hypothesis $\mathrm{H} 1$ is proved in this way.

Chi-square test shows that there is a significant connection $(\chi 2=88.985, \mathrm{df}=20, \mathrm{p}<0.001)$ between the source from which the examinees obtain information about CSR and the year in which the research was carried out, by which the hypothesis $\mathrm{H} 2$ is proved. It is noticeable that a considerable number of young people were informed about CSR via the Internet in 2012 table 4.

The biggest number of examinees think that the most used activity from CSR domain in domestic companies is social objectives promotion $(52 \%)-$ the results are presented in Figure 2. Promotion of social objectives is, according to examinees, the most used activity in every year in which the research was carried out. 


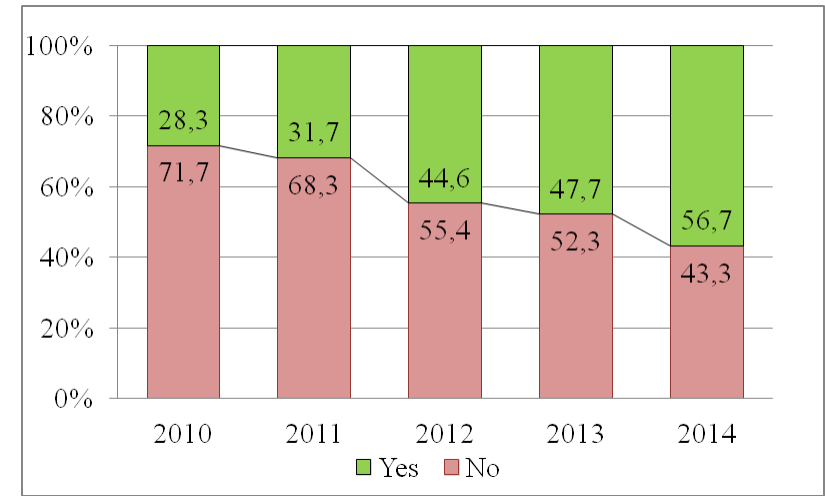

Figure 1. Understanding of the term CSR Source: Author's results

Table 4: Introducing ways with CSR term (in \%)

\begin{tabular}{|l|c|c|c|c|c|}
\hline & 2010 & 2011 & 2012 & 2013 & 2014 \\
\hline Media & 41.86 & 32.05 & 34.42 & 36.71 & 38.94 \\
\hline Textbooks & 20.60 & 33.65 & 22.22 & 28.26 & 28.35 \\
\hline Internet & 22.23 & 23.40 & 36.59 & 27.78 & 23.99 \\
\hline
\end{tabular}

Source: Author's results

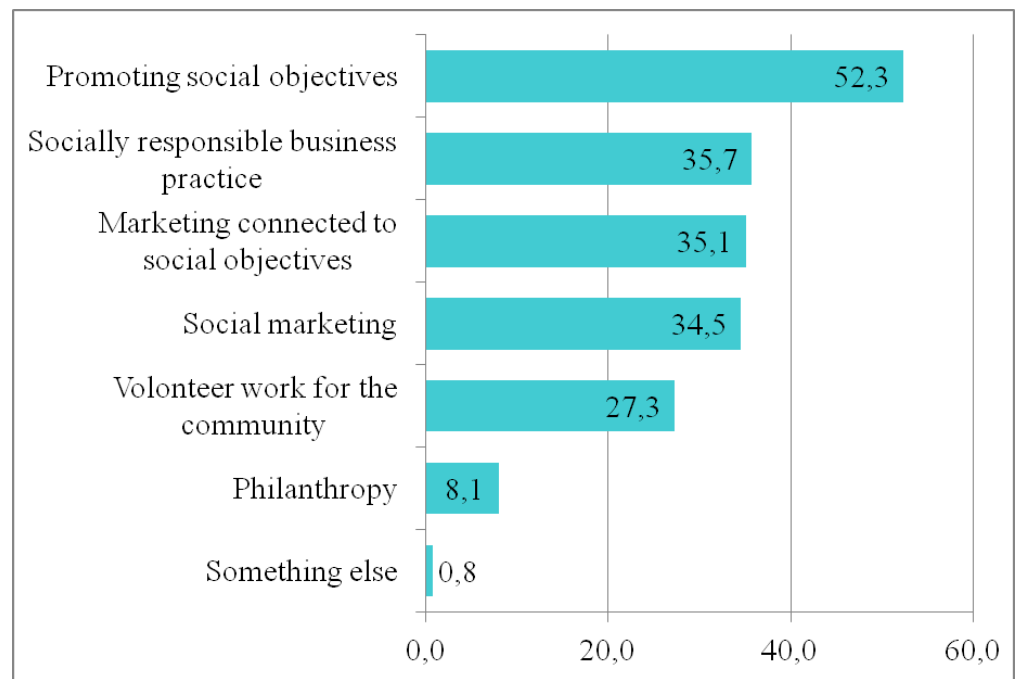

Figure 2: Most used activity from CSR domain in domestic companies (in \%) Source: Author's results

Although there is a high percentage of examinees who are not able to name the company operating on domestic market which is socially responsible organization (Figure 3.), chi-square test shows that there are differences among the years $(\chi 2=80.743$, $\mathrm{df}=4, \mathrm{p}<0.001)$ - the hypothesis $\mathrm{H} 3$ is proved in this way. Proportion tests show that, last year, there was a considerable number of young people who could name the socially responsible company operating on domestic market.

Although, in every year, there is a low percentage of examinees who think that there is a connection between competitive ability and social responsibility, chi-square test shows that there are differences between the years $\left(\chi^{2}=69,758, \mathrm{df}=4\right.$, $\mathrm{p}<0.001)$. We can see from proportion tests that in the last research year a considerably higher percentage of young people think that there is a connection between competitive ability and social responsibility, despite of the fact that it is still only $37 \%$. The elements which are recognized by the biggest number of young people as the responsible ones for development of competitive ability of domestic companies are implementation of modern methods and techniques of management and standardization of business quality (about $50 \%$ of the examinees cite each of these elements) - Figure 4. Difference tests among proportions and chisquare test $(\chi 2=562.373, \mathrm{df}=40, \mathrm{p}<0.001)$ point at the fact that in the last two years more and more young people find that the necessary elements for the development of competitive ability are the creation of CSR, implementation of modern 
management methods and techniques and standardization of business quality. Somewhat smaller number of them mention investments in national brand development as well as the creation of strategic alliances. The hypothesis $\mathrm{H} 4$ is proved in this way.

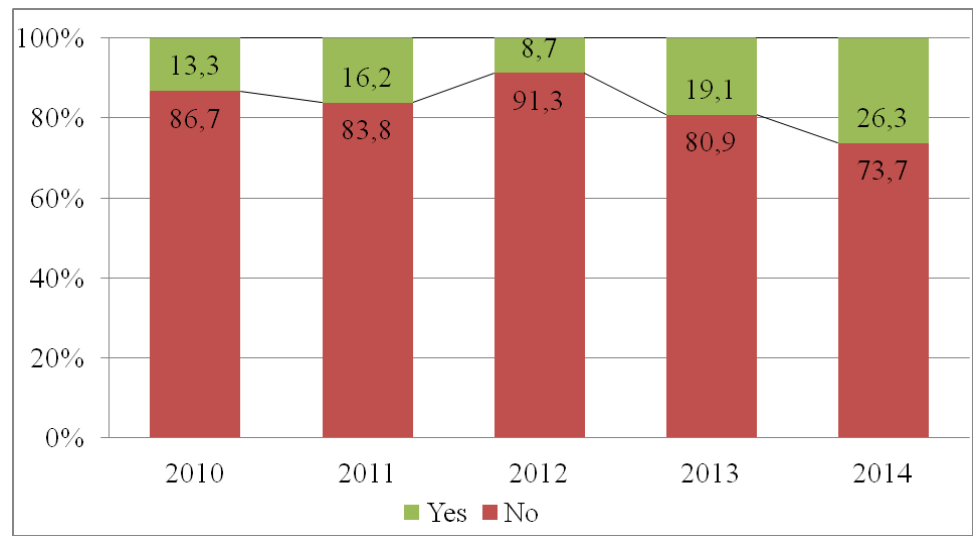

Figure 3: Recognizability of a company characterized as socially responsible one Source: Author's results

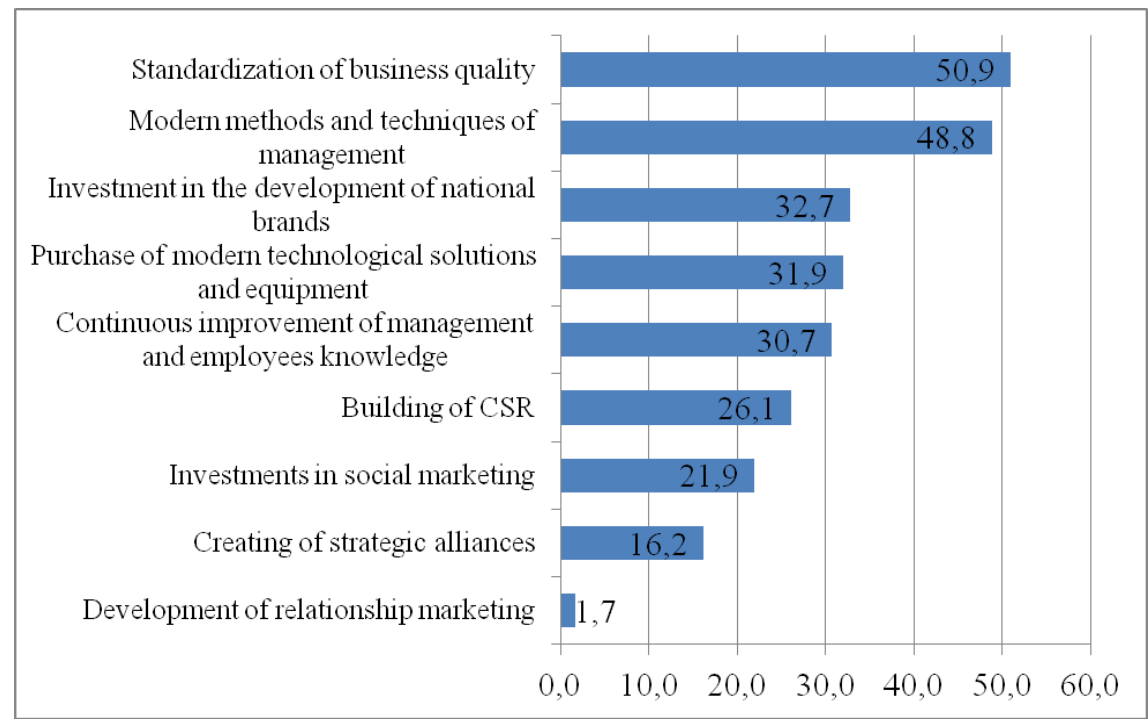

Figure 4: Necessary elements for development of competitiveness (in \%) Source: Author's results

Assessment of competitiveness related to domestic companies made by young people is relatively stable and negative during the previous five years namely, the additional decrease can be found only in 2011, but the majority of young examinees negatively assessed competitiveness of domestic companies - about $90 \%$. The assessment of innovativeness has also been at similar level during the years and it has been negative in total. A slight deviation can be seen only in 2012 when there was a small increase of the average mark, but it is still predominantly negative. Innovativeness was also assessed negatively by the majority of the examinees.

\section{CONCLUSION}

Corporate Social Responsibility as a concept enables the company to be competitive in the market. Imperative for any business enterprise is to achieve business excellence and its three pillars are: meeting the demands of users, improving business productivity and corporate social responsibility. The first two steps result in a profit, but without social responsibility of business there is no excellence of the companies.

The main problem of domestic companies is non competitiveness which is the result of poor productivity and lack of implementation of new technologies and knowledge as well as inadequate implementation of Management quality concept. Poor productivity as a rule results in poor competitive capacity. Competitiveness cannot be increased, in the long run, by subventions in industry but by improving productivity. 
Higher education in Serbia tends to follow global trends, but the theme of this work, although obviously important, still stays mainly outside the academic programs at high schools and colleges, since only a few faculty included CSR as an optional subject in their study programs. Students are poorly informed on this subject, and mainly from sources that are not relevant for educational work, where the most recognizable is Internet, which also indicates the absence of this topic in the textbooks and technical literature as well as in the study programs., There is a significant statistical difference in the surveys conducted during the several years regarding the issue of the knowledge that students have about CSR with a visible trend in the recognition and adoption of the CSR term. Poor representation of this matter in theory, as well as insufficient activity of the Serbian economy in the field of CSR, inevitably results in the complete lack information of the surveyed respondents about CSR. There is however noticeable trend of positive change on this issue, and the domestic economy recognizes the benefits of CSR, and thus shows the need to create personnel that will be capable to integrate CSR into corporate business.

However, the student population is not uninformed, and they are experiencing Serbian economy as completely uncompetitive in the international environment. Taking all this into account and considering that the relationship of CSR and competitiveness is still unclear, although there are clear facts that indicate the direction for the researches in this field, it is not surprising, that there is relatively small, but statistically significant increase in the ability of students to recognize the relationship of CSR and competitiveness, as well as other elements that may affect the competitiveness.

Students in Serbia do not have enough knowledge to be actively involved in the development of CSR and competitiveness, but there are obvious and positive trends regarding this issue. Therefore the solution is to promote the comprehensive concept of operations among young generations that has to cover several levels as follows:

- The necessity of creating a program for introducing young people to the importance and benefits of implementation of CSR and its role in improving competitiveness.

- The cooperation of several institutions that deal with young people and the economy, such as the Ministry of Education and Teacher Training, Ministry of Economy and Regional Development, the National Employment
Service, the National Agency for Regional Development, the Chamber of Commerce and Industry of Serbia, universities and colleges, associations, etc. with purpose of promoting CSR.

- Significant inclusion of CSR in business study programs.

- Stronger local media promotion of socially responsible companies, as well as awards for CSR, such as: Virtus awards and awards of Chamber of Commerce and Industry of Serbia.

\section{REFERENCES}

. Corporate Social Responsibility. (20.12.2014), from http://www.pks.rs/PrivredaSrbije.aspx?id=525\&p=0 $\&$

. Global Compact. Retrieved 20.12.2014, from http://www.unglobalcompact.org

ILO Declaration on Fundamental Principles and Rights at Work. Retrieved 20.12.2014, from http://www.ilo.org/declaration/lang--en/index.htm

OECD Guidelines for Multinational Enterprises. Retrieved 20.12.2014, from http://mneguidelines.oecd.org

. SMART: Responsible Business Initiative - RBI Retrieved 20.12.2014, from http://www.prsp.gov.rs/vest.jsp;jsessionid $=7 \mathrm{C} 36512$ 021475224148F0BE0E64B661F?id=150

. The Global Competitiveness Report 2008-2014. Retrieved 20.12.2014, from http://www.weforum.org/reports/

. Virtus Award Winners. Retrieved 17.04.2015, from http://www.tragfondacija.org/pages/virtussr/dobitnici-nagrada.php

Bansal, P., \& Roth, K. (2000). Why Companies Go Green: A Model of Ecological Responsiveness. Academy of Management Journal, 43(4), 717-736.

Bogetić, S., Đorđević, D., \& Ćoćkalo, D. (2013). Analysis of the Process of Promoting Corporate Social Responsibility in Function of Competitiveness Improvement. In S. Arsovski, M. Lazic \& M. Stefanovic (Eds.), Proceedings of the 7th International Quality Conference (pp. 143-152). Kragujevac: Faculty of Engineering.

Chand, M., \& Fraser, S. (2006). The Relationship Between Corporate Social Performance and Corporate Financial Performance: Industry Type as a Boundary Condition. The Business Review, Cambridge, 5(1), 240-245.

Ćoćkalo, D., Bešić, C., Đorđević, D., \& Bogetić, S. (2014). Socially Responsible Business and Competitiveness in Serbia - Attitudes of Students. Sovremennaa Ekonomika : Problemy, Tendencii, Perspektivy, 10(1), 141-159.

Haigh, M., \& Jones, M. T. (2006). The Divers of Corporate Social Responsibility: A Critical Review. The Business Review, Cambridge, 5(2), 245-251.

Harrison, J. S., \& Freeman, R. E. (1999). Stakeholders, Social Responsibility and Performance: Empirical 
Evidence and Theoretical Perspectives. Academy of Management Journal, 42(9), 479-485.

Hess, D., Rogovsky, N., \& Dunfee, T. W. (2002). The Next Wave of Corporate Community Involvement: Corporate Social Initiatives. California Management Review, 44(2), 110-125.

Hosmer, L. T. (1999). Somebody Out There Doesn't Like us: A Study of the Position and Respect of Business Ethics at Schools of Business Administration. Journal of Business Ethics, 22(2), 91-106. doi: http://dx.doi.org/10.1023/A:1005816001341

Ivanović-Đukić, M. (2011). The Promotion of Corporate Social Responsibility in Serbia [in Serbian]. Sociologija, LIII(1), 21-42.

Kletz, P. (2009). Research in social responsibility: a challenge for management education. Management Decision, 47(10), 1582-1594. doi: 10.1108/00251740911004691

Matten, D., \& Moon, J. (2004). Corporate Social Responsibility Education in Europe. Journal of Business Ethics, 54(4), 323-337.

McWilliams, A., \& Siegel, D. (2001). Corporate social responsibility: a theory of the firm perspective.
Academy of Management Review, 26(1), 117-127.

Milosavljević, M. (2012). Social Responsability of a Company [in Serbian]. Marketing, 43(3), 173-180.

Porter, M. E., \& Kramer, M. R. (2006). Strategy and Society: The Link Between Competitive Advantage and Corporate Social Responsibility. Harvard Business Review, 84(12), 78-92.

Porter, M. E., \& Van Der Linde, C. (1995). Green and Competitive: Ending the Stalemate. Harvard Business Review, 73(5), 120-134.

Shannon, J. R., Berl, R. L. (1997). Are we teaching ethics in marketing? A survey of students' attitudes and perceptions. Journal of Business Ethics, 16(10), 1059-1075.

Vilanova, M., Lozano, J. M., \& Arenas, D. (2008). Exploring the Nature of the Relationship Between CSR and Competitiveness. Journal of Business Ethics, 87(1), 57-69. doi: 10.1007/s10551-008-98122

Wheeler, D., Horvath, D., \& Victor, P. (2002). Graduate Learning for Business and Sustainability. Journal of Business Administration and Policy Analysis, 27, 167-187. 